\title{
China and Central and Eastern European Countries: Regional Networks, Global Supply Chain or International Competitors?
}

\author{
K. C. Fung \\ University of California \\ Iikka Korhonen \\ Bank of Finland \\ Ke Li \\ University of California \\ Francis Ng \\ The World Bank
}

\begin{abstract}
China has become leading recipients of foreign direct investment (FDI). Meanwhile, an increasing share of global FDI is going to many Central and Eastern European countries (CEECS). What is the relationship between inward FDI of China and the CEECs? We conceptualize the relationship according to three alternative paradigms: (1) China and the CEECs each exist in its own regional production network, with no linkage between FDI flows into China and into CEECs; (2) China and the CEECs together comprise a global production network, so that China's FDI is positively related to CEECs' FDI; and (3) FDI into China is a substitute for FDI into the CEECs, with the correlation being negative. In this paper, we study empirical estimates of this issue for 15 CEECs for

*K.C. Fung: University of California, Santa Cruz, e-mail: kcfung@ucsc.edu, Iikka Korhonen: Bank of Finland, e-mail: iikka.korhonen@bof.fi, Ke Li: University of California, Santa Cruz, e-mail: Kli@ucsc.edu, Francis Ng: The World Bank - Development Research Group, 1818 H Street, NW, Washington DC 20433, Tel: 202-473-8088, Fax: 202-522-1159, e-mail: fng@worldbank.org. (C2009-Center for International Economics, Sejong Institution, Sejong University, All Rights Reserved.
\end{abstract}


1990-2004 using four different econometric approaches: FGLS with Random effects, FGLS with fixed effects, EC2SLS and GMM. The result supports the conclusion that China's inward FDI does not crowd out CEECs' inward FDI. In fact, it shows that in some regressions FDI flows in these two regions are moderately complementary. Our analysis also confirms the importance for FDI flows of determinants such as market size, degree of trade liberalization, labor quality and a healthy global FDI supply.

- JEL Classifications : F20, F21, F43

- Key Words: foreign direct investment(FDI), regional networks, global supply chain, China's FDI, central and eastern european countries' FDI

\section{Introduction}

The past two decades have been the most significant period in the growth of foreign direct investment (FDI) into China. Starting from a modest base of $\$ 3.49$ billion in 1990, China's FDI inflows expanded rapidly, to a peak of over $\$ 44.2$ billion in 1998. A further surge accompanied China's accession to the World Trade Organization (WTO) in December 2001, lifting China to the top ranks as a FDI destination in 2003. In 2005, China's inward FDI reached a record high of over $\$ 70$ billion.

Governments from other emerging markets are very concerned about this unprecedented growth. As they would point out, world FDI grew in the same period at a very modest rate. This turn of events suggests the possibility that persistent rapid growth of FDI into one country or region (e.g. China) will eventually hollow out inward FDI shares of other emerging markets. This potential phenomenon has been dubbed the 'China effect'. Researchers and policymakers from the emerging countries have on various occasions expressed some concern about the situation, and it is now clear that an empirical analysis leading to some convincing results is both urgent and necessary. ${ }^{1}$

While the recent related literature is focused on the relationship between China and other Southeast Asian and Latin American countries, much less attention has been paid to regions such as the Central and Eastern Europe. Historically, the European Union (EU) has always been the primary source of FDI flows into the

${ }^{1}$ Chantasasawat, et. al. (2004) and Eichengreen and Tong (2005) cited some concerns by scholars and policymakers in East Asia and Latin America about this potential "China Effect". 
Central and Eastern European countries (CEECs). At the time when most CEECs were opening their doors to western direct investment, after the transition in the early 1990s, the more advanced economies in the region (Czech Republic, Hungary, and Poland) were well-positioned to attract large inflows of FDI. Their main advantages in this regard include close geographical and cultural ties with traditional EU members as well as initially low wage levels. Meanwhile, as remarkable economic progress in Southeast Asia in the 80s and 90s caught the attention of the rest of the world (including the EU), an increasing share of world FDI began to flow into the region in 1996. China, being the region's most successful performer in terms of economic growth, has become one of the most important host markets for European Union FDI. The dramatic increase of FDI into both China and the CEECs raises much concern over whether there is an overall substitution or complementary effect on FDI attraction between the two regions. In particular, one might wonder whether China's emergence as a top FDI recipient tends to crowd out FDI flows into CEECs. Since both China and CEECs have benefited a great deal from FDI inflows over the last two decades, this is apparently an issue of great interest to academic scholars and policymakers from both regions.

As the starting point for our study we take a major insight from the existing literature on FDI into different emerging market economies, viz. that such FDI is often motivated by the need to facilitate production networks. ${ }^{2}$ We conceptualize our approach by considering three alternative scenarios for the relationship between FDI flows into China and into the CEECs. The first is that China itself is only a part of the Asian regional production network, so that its inward FDI is not related to the CEECs' inward FDI. A second possibility is that the Chinese and CEEC economies are all parts of a global production network, so that FDI into China and into the CEECs are complements. Lastly, we can take the position of multinationals considering China and CEECs to be rival production sites, so that FDI into China and into the CEECs are substitutes.

The aim of this paper is to investigate our proxy for the impact of China, along with other FDI location determinants, within an analytical framework. Using panel

\footnotetext{
${ }^{2}$ Several econometric studies have found that FDI is positively correlated with trade in components and parts after controlling for other relevant variables, at least in East and Southeast Asia, see e.g. Aminian, Fung, lizaka and Siu (2008). For a company case study, see the Alliance Asia Group, which provides supply chain services in consumer electronics and computer peripherals between Asia and Eastern Europe, with operations in Hungary, Romania, Serbia, Shenzhen, Shanghai and other cities. Their website can be accessed at http://www.sowah.hu.
} 
data on 15 CEECs spanning the period from 1990 to 2004, this empirical study tries to shed some light on the relationship between the two regions in terms of FDI attraction and broader economic cooperation. The paper is organized as follows. Section 2 gives a background review on FDI development in the two regions. Section 3 describes the data and estimation methodology, and Section 4 presents the estimation results. Some robustness checks are discussed in section 5 , and Section 6 concludes.

\section{FDI into China and into Central and Eastern Europe since 1990}

Since it first adopted an open-door policy in 1978, China has experienced several phases in inward FDI from the rest of the world (Figure 1). In the first stage, from 1979 to the mid-1980s, only a parsimonious amount of FDI flowed into the country each year, due to its insufficient infrastructure and regulatory obscurity. Later, FDI inflows increased at a fairly steady rate until they slumped in 1990 as a result of politically-motivated economic sanctions. It was not until 1992, when then-Chinese-leader Deng Xiaoping toured Shanghai and Guangdong carrying a message of renewed commitment to open up the market that the value of annual FDI inflows jumped again to a new high of $\$ 11.2$ billion. This rapid surge continued through the following years until it was stemmed again by the Asian financial crisis in 1997. China has since 2000 regained momentum in attracting FDI. Its accession to WTO in 2001 brought a new surge of FDI inflows. Despite a worldwide decline in FDI, China continued to gain in global FDI share, overtaking the United States to become the world's second largest FDI destination in the early 2000s. Among those investing in China, the major players are the industrialized and newly industrialized countries. Until the mid-1990s, Hong Kong was the largest source, accounting for more than 50 percent of the nation's total FDI inflows, followed by Taiwan, the U.S., Japan, Singapore, U.K., South Korea, Canada and Germany. In recent years, there has been a downward trend in Hong Kong's share and increasing shares of other regions, which has made for a more diversified pool of FDI into China. Meanwhile, accompanying the double digit growth of the nation's inward FDI are some notable changes in its structure. In the early period, FDI was allowed only for a small number of industries largely due to the government's cautiousness concerning the dominance of foreign capital in many industries. Later on, especially after Deng's southern tour in 1992, many other industries opened up to foreign investors. With more foreign capital entering 
Figure 1. FDI Inflows and FDI Stock in China, 1980-2005

FDI inflows in China, 1980-2005

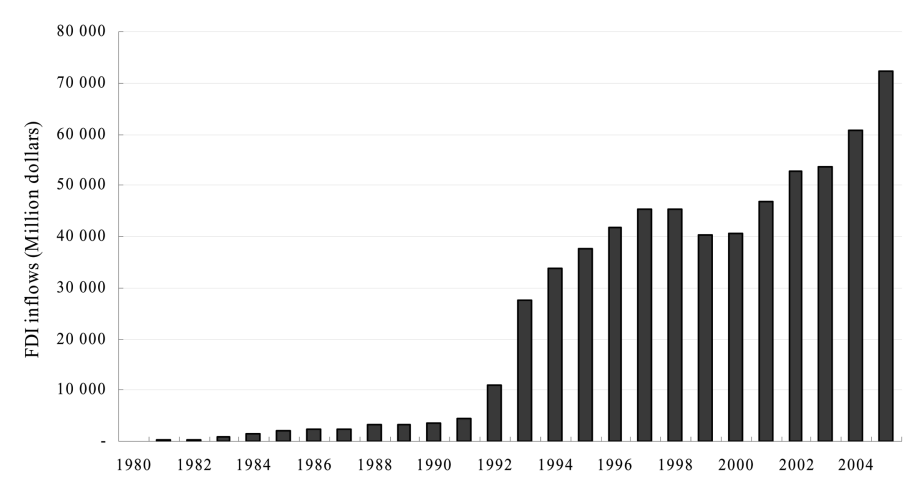

FDI stock in China, 1980-2005

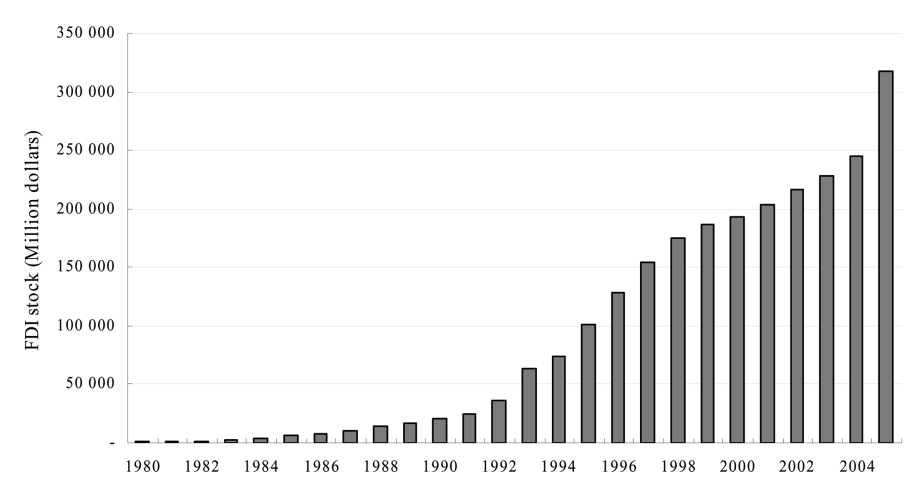

Source: UNCTAD World Investment Report online database

industries such as manufacturing, retailing, real estate, transportation, and banking, FDI into China began to shift from labor and capital intensive to mainly technology-based manufacturing, with increasing shares for the service sectors (Figure 2).

Similarly, FDI flows into the Central and Eastern European Countries (CEECs) show a steady growth pattern over the last two decades. Beginning in 1989, all CEECs began a transition from communist central planning economy to free market economy. In the area of the former Soviet Union, transition started later, and only the dissolution of the Soviet Union in 1991 allowed a significant change in the policy. Even then, the early years of transition in the former Soviet Union (FSU) countries were hampered by the challenges of nation-building. Most FSU countries, with the notable exception of the three Baltic countries, are still lagging 
Figure 2. Distribution of China FDI Stock by Industry and Country of Origin, 1990-2004
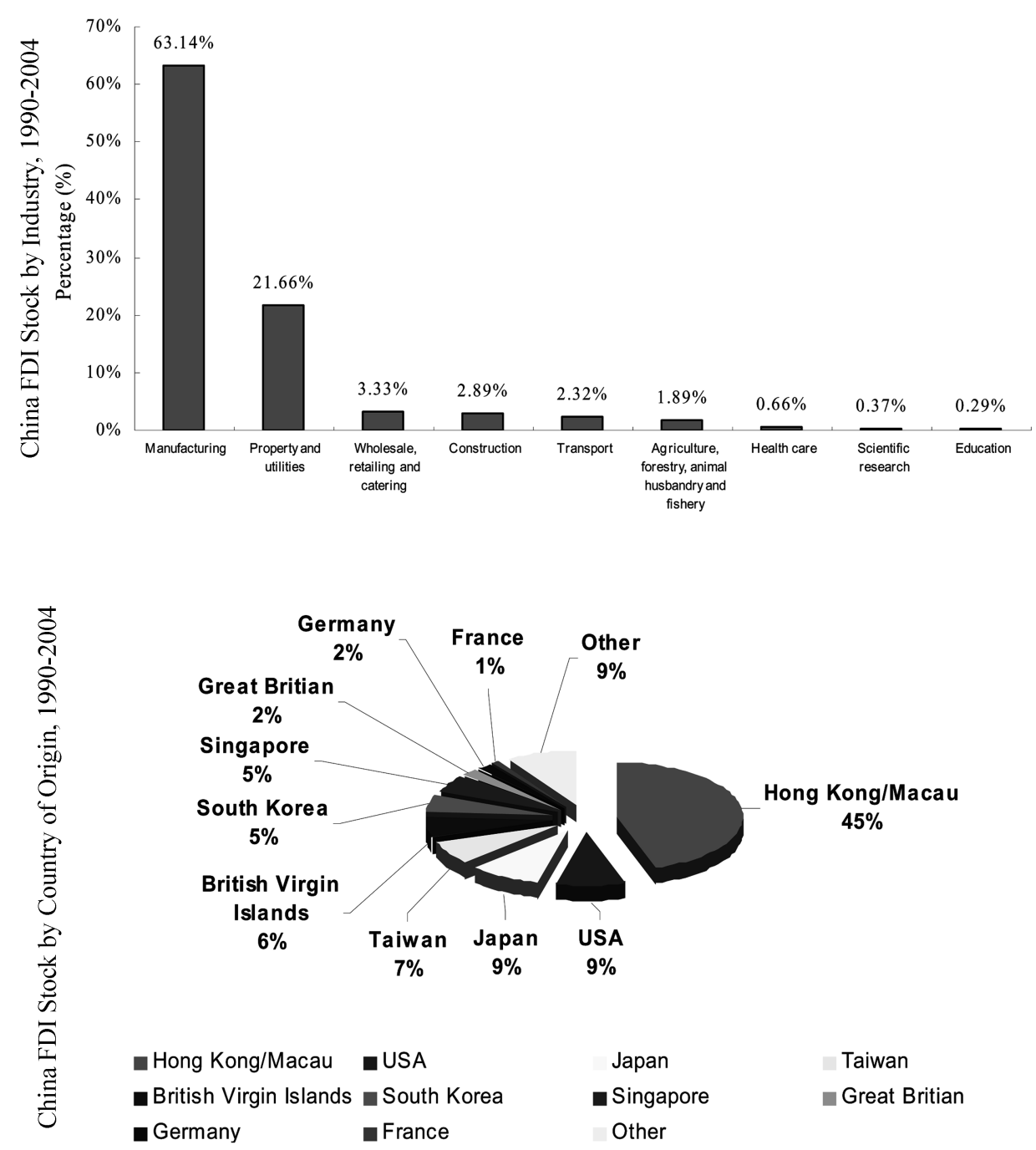

Source: National Bureau of Statistics of China, 2005

behind the CEECs in implementing reforms.

As a result of this profound political and structural change, annual FDI flows into the region, of which a majority came from EU countries, began to expand rapidly from a low level. However, drastic economic and political reforms in the CEECs at the start of the transition caused almost all members to suffer economic recession of varying degrees. Consequently, FDI inflows in that period were adversely affected. Starting in 1994, regional FDI picked up, largely due to 
successful transitions by many of the CEECs. The nearly-doubled annual FDI inflows during this period, from $\$ 12.3$ billion in 1995 to $\$ 23.5$ billion in 2000 , were mainly induced by large-scale of privatization in the more advanced CEECs. For example, the purchase of a majority share in Poland's Telekomunikacja Polska by France Telecom for $\$ 4$ billion in 2000 was one of the largest privatization and FDI transactions in the region. The European Bank for Reconstruction and Development (EBRD) compiles annual indicators depicting progress in structural reforms related to the transition to market economy. EBRD (2007) shows the progress in both large-scale and small-scale privatization in our sample countries between 1990 and 2004. (Here a value of 4.0 denotes the level of reform comparable with a fully functioning market economy and 1.0 denotes a completely unreformed economy.) In Figure 3 we can see that many countries in Central and Eastern Europe had completed the large-scale privatization by the mid-1990s, while in a few countries the process was still incomplete in the mid-2000s. However, it seems that the countries that moved fastest in privatization were also able to attract more FDI.

With most privatization processes in the region's advanced economies nearing completion, the structure of FDI flows into CEECs was expected to shift from privatization towards more technology-intensive greenfield projects and large cross-border mergers \& acquisitions. This surge of inward FDI also encouraged less developed southeastern European countries to continue with their structural and institutional reforms, which has accelerated the liberalization and privatization

Figure 3. EBRD Indicator of Progress in Large-scale Privatization

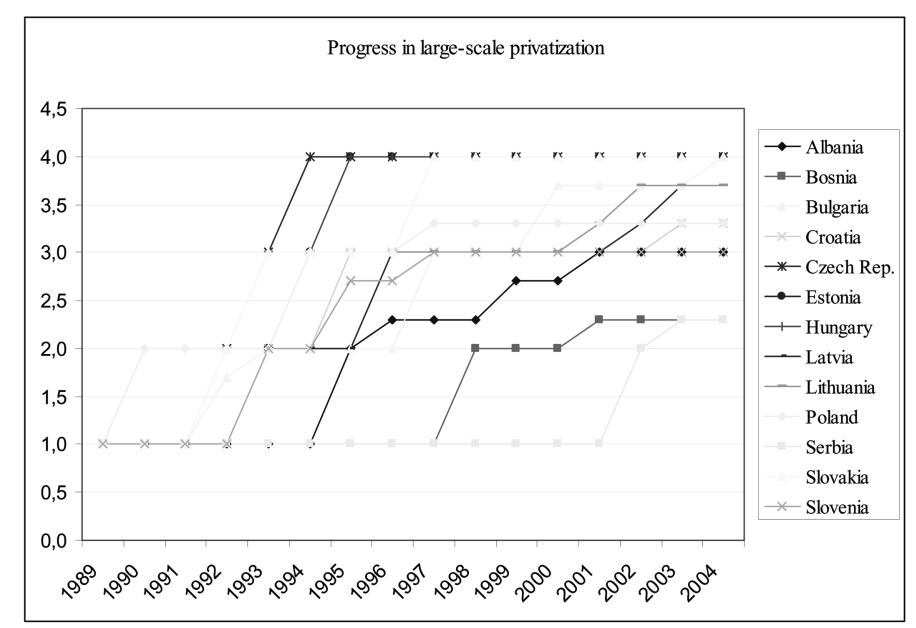

Source: EBRD, 2007 
Figure 4. FDI Inflows/Stock to China and 15 CEECs as Percent of World Total, 1990-2005

FDI Inflows to China \& 15 CEECs as a Percent of World Total, 1990-2005

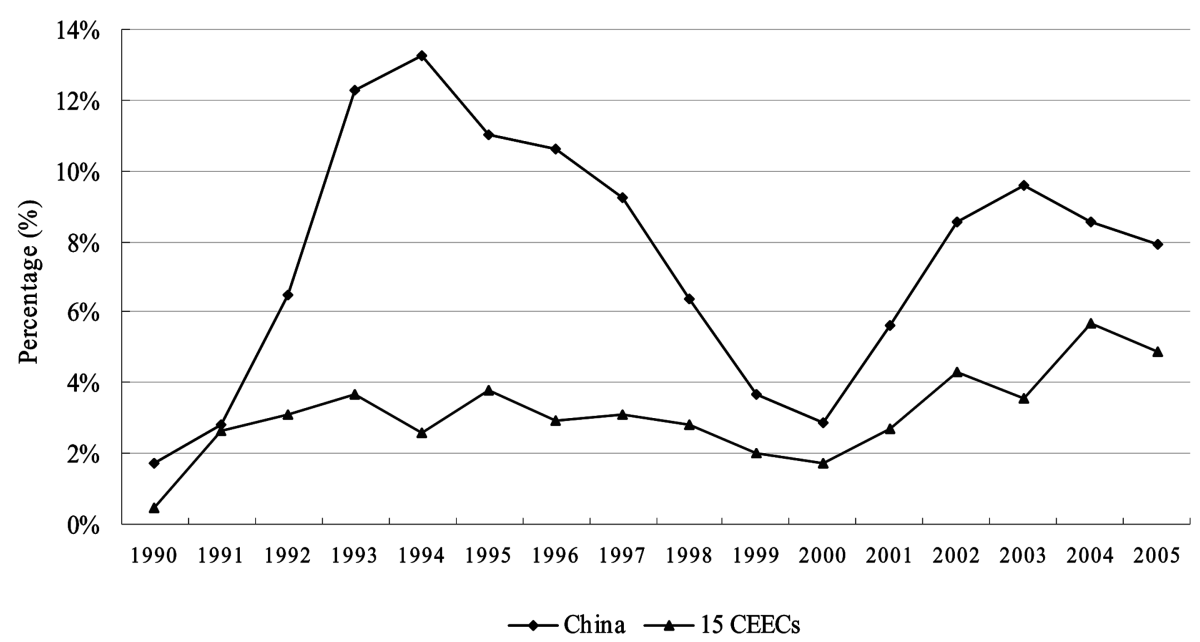

FDI Stock in China \& 15 CEECs as a Percent of World Total, 1990-2005

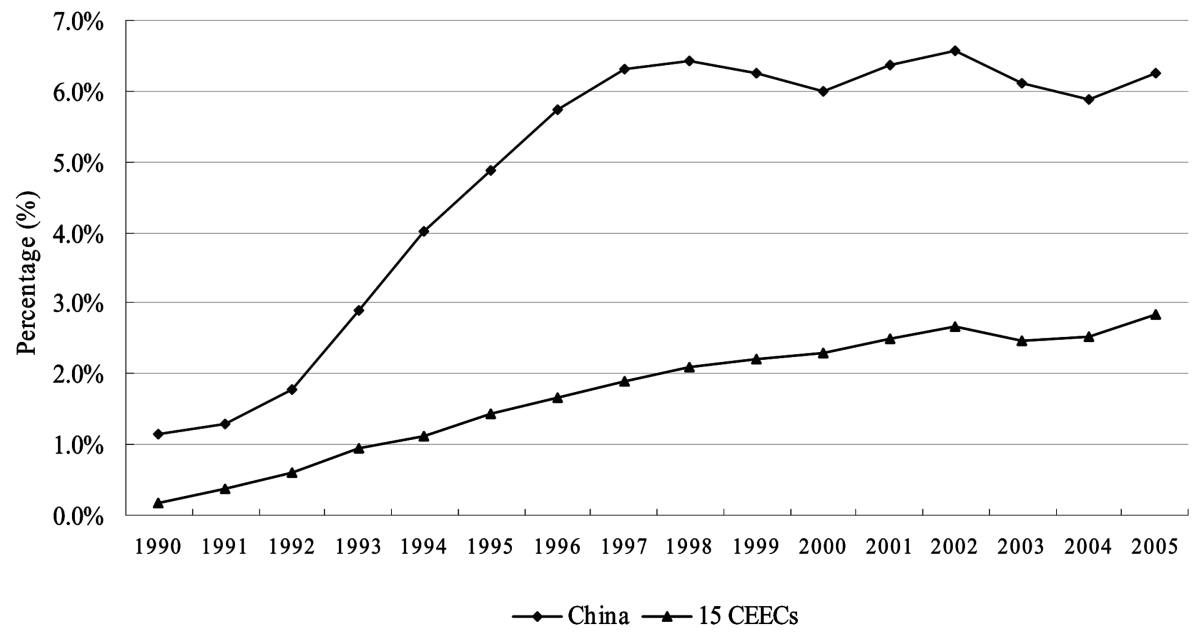

Source: UNCTAD World Investment Report online database and authors' own calculation

of state-owned enterprises and led to reductions in corporate tax rates and bigger tax exemptions and other incentives to foreign investors. One thing to note is that, even with the rapid growth of FDI into the region, there is still a high degree of variation in the distribution of FDI, with disproportionately large shares going into the more advanced states (Hungary, Czech Republic, Poland and Slovakia). Moreover, the sectoral distribution of FDI may differ between the CEECs and 
China, as well as among the CEECs themselves. For example, EBRD (1998) notes that already in 1997 some 40-60 per cent of the FDI stock in the CEECs was in the manufacturing sector, while the importance of services was increasing rapidly, especially in the more advanced countries.

During the last 15 years, EU trade and FDI with China has continued to increase. In 1999, EU-originated FDI accounted for 11 percent of China's total inflow, making it the second largest source after Hong Kong. Meanwhile, due to the geographical and cultural proximity between CEECs and the EU, the latter accounted for more than 79 percent of CEECs' FDI inflows in the past 15 years. Thus, both China and CEECs consider the EU countries as their major sources of FDI inflows. The similarity between CEECs and China is also clear. They were both marked by a central planning economy under communism before the transition. Most of the foreign trade was accomplished within the socialist block. Starting as early as 1989 , they began the transition from central planning to market economy. However, there is still a big difference as to the paths taken during the reform. While many CEECs adopted a comprehensive economic and political restructuring with a precipitate privatization process, China focused more on economic reform alone. This discrepancy, together with other factors such as different host-country comparative advantages, contributes to the variation in FDI recipients and trade patterns between the two regions. As noted in Sachwald (2004) in comparing FDI from the US, Japan and the EU, they found that most US and Japanese Multinational Corporations (MNCs) are interested in China in the role of manufacturing platform via vertical channels while their European counterparts favor a horizontal linkages in their domestic markets. A survey of international investors also indicates that, among the decisive factors in determining FDI destination, a relatively highly skilled labor force in line with production needs in CEECs is the most important attribute driving their investments in the region.

Meanwhile, the fifth EU enlargement ${ }^{3}$ with accession to the Central and Eastern European countries brings the opportunity for European investors to extend their operations in new member states. With access to a larger market and free movement of capital and labor resources across member states, foreign investors are more inclined to participate in the local economy for reasons of comparative advantages. Early literature has empirically supported the positive impact of

\footnotetext{
${ }^{3}$ The European Union has undergone five enlargements, the largest on May 1, 2004, when 8 of 10 new members were CEECs - Czech Rep, Estonia, Hungary, Latvia, Lithuania, Poland, Slovakia and Slovenia.
} 
increased integration in the European Union. Norman (1995) showed that the process of regional integration in the EU resulted in rapid growth in intra-EU FDI, contributing to the increase in intra-EU FDI from 25 percent of total inward stock in 1980 to 40 percent in 1988. Parallel to those studies which focus on the benefits of FDI for the host market, recent literature goes the other way by tackling the possible crowding out effect of FDI as a result of the fifth EU enlargement. They are particularly concerned that too much FDI redistribution from old western members to new eastern ones could mean substitutions for those traditional FDI destinations, thus hurting their economies. Barry and Hannan (2001) and Barry (2002) compare Ireland with new members among CEECs and conclude that the similarity between the two when joining the European Union (relatively low economic development level and cheap labor costs compared to other member states) can lead the latter to follow a similar development trajectory. In terms of FDI substitution, the authors propose two possible directions, both of which have found supporting evidence. On one hand, the fifth enlargement contributes to an increase in total FDI in both old and new member states. On the other hand, benefiting from technology spillovers and structural improvement due to FDI, CEECs are now in a better position to compete with other old member states, causing a potential diversion of FDI flows. Indeed, similar patterns can be expected in other parts of the world as well.

Given both China and CEECs' enlarging share of world FDI and the similarities and differences in their economic and institutional reforms, one may wonder whether FDI inflows to the two regions are at all correlated, and if so, are they complementary or competitive? It is believed that a clear understanding of the exact relationship between the two is not only beneficial to both economists and policymakers for research and policy purposes, but also crucial in the current wave of globalization. However, up until recently, there has still been insufficient research that makes comparisons between China and Central and Eastern Europe as favorable targets for global FDI. Empirical studies that try to quantify the potential impacts between them are even fewer. In this regard, our paper aims to provide an empirical analysis of the above issues. In particular, we want to show whether China's continuing economic expansion, by appealing to foreign investors in terms the nation's comparative advantage in labors costs and large market, diverts global FDI from CEECs, the so-called hollowing out effect. Or is China's success in becoming a world center for further processing and assembling, while establishing an efficient production network and supply chain and consequently 
enhancing the productivity of other emerging markets including CEECs, indirectly strengthening the latter's ability to attract further FDI (the case of complementary)? The potential global supply chain linkage between China and CEECs can be illustrated by the some of their trade patterns and some sectoral FDI distributions. For example, in 2006, China exported US\$5,296 million of parts and components to the CEECs and imported US\$1,068 million of parts and components from the CEECs. In addition, in 2005, 10.4 percent of inward FDI to Hungary was in the sector "Motor Vehicles and Transport Equipment" and another 8.9 percent was in "Electrical and Electronic Equipment", two sectors with well-known supply chain activities.

\section{Data and Methodology}

Given the purpose of empirically investigating the correlation between China and Central and Eastern European countries in attracting foreign direct investment from the world, a model is constructed by regressing host country FDI inflows on the China effect variable (here, China's FDI inflows) while controlling for a set of host characteristics. Therefore, a statistically significant estimate of the China effect would be considered proof of a strong correlation. The data used in the model are panel data spanning the period from 1990 to 2004 for 15 CEECs. They are Albania, Bosnia and Herzegovina, Bulgaria, Croatia, Czech Republic, Estonia, Hungary, Latvia, Lithuania, Macedonia FYR, Poland, Romania, Serbia and Montenegro, Slovakia and Slovenia. Thus, the number of observations in the panel is $225(15 \times 15)$. We focus on the period starting in 1990 because we believe it fully covers the transition period and thus helps us gain a thorough understanding by incorporating time trends and growth patterns of FDI inflows in the region.

With all variables converted to $\log$ form except those presented as percentages ${ }^{4}$, our benchmark regression takes the form

$$
\begin{aligned}
& \ln F D I_{i, t}=b_{0}+b_{1} \ln C F D I_{t}+b_{2} \ln F D I_{i, t-1}+b_{3} \text { GPCGR }_{i, t}+b_{4} \ln G D P_{i, t}+b_{5} \ln W F D I_{t} \\
& +b_{6} \ln W A G E_{i, t}+b_{7} I_{L L I T_{i, t}}+b_{8} \text { OPEN }_{i, t}+b_{9} \text { TARIFF }_{i, t}+b_{10} I_{N C T A X_{i, t}}+b_{11} P S R_{i, t} \\
& +b_{12} \ln T E L E_{i, t}+b_{13} A_{C C E S S_{i}+u_{i}+v_{i, t}}
\end{aligned}
$$

where subscripts $i$ and $t$ denote country $i$ in year $t$ and $u_{i}$ denotes the countryspecific effects and $v_{i t}$ the disturbance term.

${ }^{4}$ See detailed data description in Appendix. 
Our dependent variable is annual foreign direct investment inflows to the 15 CEECs. As defined in IMF (1993), direct investment is "investment that is made to acquire a lasting interest in an enterprise in an economy other than that of the investor, with a purpose of having an effective voice on the management level." Such management control usually requires a minimum of 10 percent ownership of investors for the investment to be classified as direct. Our data for FDI inflows are drawn from UNCTAD interactive database.

The independent variables included in the model are expected to influence individual host-country FDI inflows through both economic channels, such as foreign trade and economic growth, and the environmental channel comprising changes in institutions and policy. One thing that interests us most is the use of China's FDI inflows as a proxy for the China Effect. According to Chantasasawat, Fung, Iizaka and Siu (2004), there are two lines of reasoning to support the inclusion of this variable. One major objective of foreign direct investment is to exploit comparative advantage in a host country. In deciding on investment destination, Multinational Corporations (MNCs) often choose among several comparable candidates the one with the lowest labor costs. Under this scenario, an increase in FDI inflows to the country with the lower labor costs must come at the expense of reducing the inflows to others, thus generating a "hollowing out" effect. It is not unusual nowadays to hear of concern from various sources that the emergence of China as a top FDI recipient diverts FDI flows away from other countries. While this is a major concern, an equally strong and empirically sound argument suggests that rapid growth of FDI inflows to one country, via production network and supply chain linkages, can stimulate similar growth in its neighboring and other economies. With further integration and cooperation across borders, an increasing portion of the production processes from MNCs now reflect specialization and fragmentation, which necessitate large investments within a set of production networks. Member countries, with their respective advantages across distinct stages of production, all benefit from large inflows of foreign investment. Empirical studies in the literature present a mixed picture of correlations between country-wise FDI inflows. As pointed out in Cravino, et al (2006), the emergence of China in the global economy has had positive effects on global FDI flows. Lall and Zhou (2005) suggest that China boosted, rather than diverting, FDI flows to its neighboring countries. Eichengreen and Tong (2005) find that growth in China's FDI inflows encourages FDI into other Asian countries but diverts FDI away from OECD countries. In our case, the above two effects would imply opposite signs on 
the proxy variable, and it remains to be seen which effect stands dominant.

As mentioned earlier, we can consider this issue by examining three alternative hypotheses: China (together with East Asia) and CEECs being in their respective regional production network, so that the estimated coefficient of the China effect would be expected to be zero. A second hypothesis is that China and CEECs are in the same global supply chain (coefficient of the China variable expected to be positive). Lastly, China and CEECs could be rivals in the eyes of global multinationals, so that the sign of the China effect would be negative.

Our model also controls for a potential agglomeration effect of FDI in transition economies. Various empirical works (Head, Ries and Swenson, 1995) suggest the existence of an agglomeration effect in most FDI activities. Such an effect obtains when investors believe they can benefit from herding within the same location. To them, these benefits include (though not limited to a better supplier network) sufficiently skilled labor and enhanced productivity, all of which are crucial to profitable long-term investment. Moreover, accumulation of FDI from investment herding may generate positive feedback on the superiority of the local investment environment to potential investors of interest and thus lead to more FDI inflows. We use a one-year lagged value of FDI inflows to accommodate the agglomeration effect.

Meanwhile, host-country macroeconomic conditions are among the foremost considerations in an MNC's location decision. Countries with stable economic growth and above-average market size are more likely to have production capacity and large demand and are therefore favored as investment destinations. We consider the host country's growth of per capita real GDP and annual real GDP to be good indicators of its economic growth and market size. Data for real GDP and per capita GDP are drawn from the World Bank's World Development Indicators. Real GDP data are measured in constant 2000 US dollars.

It is well substantiated that country-specific institutional and policy factors are important to an MNC's investment location preference. Easy access to market, favorable investment regulations as well as domestic political stability are all among the prime factors for the investment destination. However, to correctly interpret the findings on determinants of FDI, one should distinguish between two types of FDI in terms of the motivation. Market-seeking or horizontal FDI, with a focus on the market in the host country, chooses local production to avoid the associated costs of trade. It is the type that dominated FDI flows in the early days and is still important in today's global economy. Apart from that, is the so-called 
cost-minimizing or vertical FDI, in which investors pick investment locations for each link of the production chain so as to reduce the overall costs. Hanson, Mataloni and Slaughter (2001) indicate that recent surge of FDI inflows, especially to the South, is mainly of the vertical form. A similar conclusion is also found in Markusen and Maskus (1999). The different types of FDI will have different implications for location determinants, e.g. market size, trade restrictions. In our analysis, trade restrictions are controlled for by including both import tariff rates and openness to trade. Import tariff rates are collected from IMF Government Finance Statistic Yearbook as well as national statistical agency websites and are measured as percent of import tariffs in total revenue from international trade and transactions. And openness to trade is calculated as the ratio of country's trade turnover to its GDP.

In line with the distinction, labor costs, which are considered to be another important determinant of investment flows, may also exert a different impact. It is argued that vertical FDI, by taking advantage of comparatively low production costs in the host country, should be negatively related to it. In Bedi and Cieslik (2002), the evidence indicates a strong negative correlation between FDI and wage levels in Poland. Hunya (2004) pointed that after the first wave of vertical FDI flows into CEECs, FDI has shifted "further East" due to increasing labor costs. In the case of horizontal FDI, generally a negative sign would again be expected (for cost reasons), albeit this may no longer be the top priority in investors' decision making. However, this does not exclude the possibility of positive relationships in some instances. One would expect a positive sign on wage rate to reflect the purchasing power and labor quality of the local market. To control for this factor, we use wage rate in manufacturing as a proxy. International Labor Organization's LABORSTA provides data on individual countries' manufacturing wages in local currencies. We convert the wage rates to US dollars via official average exchange rates from World Development Indicators. As to labor quality, we include the illiteracy rate for the host population as a proxy. Using illiteracy rate data from United Nations Education, Scientific and Cultural Organization (UNESCO)'s Institute for Statistics, we calculate the percentage of people aged at least 15 who are illiterate.

In terms of institutional variables, it is widely accepted that host-country political, as well as financial, risk is critical to its overall economic well-being. This is more so in our case because almost all CEECs experienced political instability and economic slump at the onset of transition. As pointed in Navaretti and Venables (2004) "political risk and instability seems to be an important deterrent to 
inward FDI". Henisz (2000) demonstrates that political and contractual hazards may go hand in hand since transactions that originally should have been effectively organized through contractual agreements are more likely to lead to arbitration or court Fights. Equally detrimental to inward FDI growth are host-country financial instability, corruption and social disorder. Corruption is believed to induce uncertainty over the business environment and to discourage FDI inflows. Lack of legality indicates weak protection in case of need and therefore further aggravates the investment environment. We adopt the International Country Risk Guide (ICRG) group index of political stability risk (PSR) as a proxy for institutional and political quality of the host country. The index incorporates 12 risk categories (bureaucratic quality, corruption, democratic accountability, ethnic tensions, external conflict, governmental stability, internal conflict, investment profile, law and order, military in politics, religious tension, and socioeconomic conditions) and is calculated as a weighted sum of 100 (a higher score corresponds to less risk and greater stability).

Tax burden is another factor that concerns potential foreign investors when choosing a location for FDI. As one would expect, a high income tax rate for business might mean a narrower profit margin, which could deter FDI. Wei (2000) finds support for a significant negative relationship between corporate income tax rate and FDI attraction. Another topic of discussion in the literature concerns the host country's infrastructure quality. According a survey for the World Investment Directory (2003), large FDI projects are partially driven by the infrastructural quality of the host economy. The World Economic Forum's Chief Economist, Augusto Lopez-Claros (2005), has stated that "an inadequate supply of infrastructure is rated by business as the biggest obstacle to operation in foreign affiliates and improving basic infrastructure would drive up FDI". Fung, Iizaka and Parker (2002) and Fung, Iizaka and Siu (2003) find positive evidence that Chinese provinces with better infrastructure are more likely to become FDI destinations. Our data for the corporate income tax rate are collected from various issues of Price Waterhouse Cooper's Worldwide Tax Summaries and European Tax Handbook. Our proxy for host-country infrastructure quality is the number of telephone mainlines per thousand people, from World Development Indicators.

Factors that control for every host country's FDI recipients include the current global supply characterized by world FDI outflows. Other things equal, a jump in FDI outflows worldwide is expected to have a positive effect on FDI inflows to all host countries. Therefore, annual world FDI outflow is added in our analysis to 
include this supply side effect. Data on world FDI outflows are drawn from the UNTCAD interactive database.

In addition, the fifth EU enlargement, by granting accession to eight CEECs, is likely to be a sign of credibility to foreign investors as regards these countries' institutional and economic reforms. In recognition of their strong improvement, foreign investors are more confident about choosing to operate in these economies. In this connection, an accession dummy is constructed, taking the value of 1 for each of the eight CEECs that are member states and 0 for the other seven. Since the accession dummy is time invariant, estimation for either the fixed-effect model or the first-differenced Generalized Method of Moments (GMM) will eliminate it from the regression. In order to recover the estimates for accession, we make a transformation by interacting it with a time trend. ${ }^{5}$

Given the panel structure of our data, a host of methods are available for estimation. One common issue that arises in the estimation of panel data is whether the individual effects are considered "fixed" or "random". For comparison, we estimate and report both fixed and random effects from use of the Generalized Least Squares method. Another problem with our analysis is the potential endogeneity of the lagged value of FDI inflow and the proxy for the China effect, China's FDI inflows. One can argue that neither variable is strictly exogenous to the dependent variable, FDI flows into CEECs. Some omitted factors can simultaneously affect both variables, making them endogenous and correlated with the error term (e.g. a worldwide technology shock that increases FDI into China is expected to likewise enhance FDI into CEECs; Eichengreen and Tong (2005) note that an improvement in investor sentiment worldwide may be another example of such endogeneity). One solution is to use instrumental variables. In our analysis we adopt the Error Component Two Stage Least Squares (EC2SLS) model of Baitagi $(1981,2001)$, which is the IV analog of a random-effects model. In the first stage of EC2SLS, the endogenous variable is regressed on all of the exogenous variables in the system, which are modified by the "within" transformation and the "between" transformation, plus any exogenous instruments that we use. ${ }^{6}$ In the second stage, the outcome variable is regressed on the exogenous variables with the predicted value from first stage replacing the endogenous variable.

Meanwhile, in the context of the endogeneity problem, another estimation

\footnotetext{
${ }^{5}$ The accession dummy is country-specific and time-fixed across the period.

${ }^{6}$ The exogenous instruments used are most of the independent variables from the China FDI equation, e.g. China GPCGR, GDP, WAGE, OPEN, etc.
} 
Table 1. Summary Statistics

\begin{tabular}{cccccc}
\hline Variable & Obs & Mean & Std. Dev. & Min & Max \\
\hline FDI $^{\dagger}$ & 202 & 1130 & 1850 & 0.01 & 12600 \\
CFDI $^{\dagger}$ & 225 & 34900 & 16000 & 3490 & 54900 \\
GPCGR $^{\dagger}$ & 211 & 2.346 & 9.967 & -31.34 & 86.35 \\
GDP $^{\dagger}$ & 218 & 27100 & 37000 & 1120 & 192000 \\
WFDI $^{\dagger}$ & 225 & 537000 & 319000 & 188000 & 1240000 \\
WAGE & 161 & 295.833 & 206.572 & 32.72 & 1174.9 \\
INCTAX & 126 & 29.892 & 8.219 & 5 & 45 \\
TARIFF & 139 & 4.141 & 3.781 & 0 & 18.57 \\
OPEN & 211 & 96.803 & 32.765 & 34.82 & 180.36 \\
ILLIT & 170 & 2.711 & 4.905 & 0.2 & 23.04 \\
PSR & 155 & 70.229 & 10.713 & 26 & 87 \\
TELE & 220 & 238.424 & 99.738 & 12.16 & 424.91 \\
\hline
\end{tabular}

$\dagger$ : in millions

method, the Generalized Method of Moments (GMM) Instrumental Variable estimator for dynamic panels, has been proposed by Arellano and Bond (1991). This method can yield consistent estimates with greater efficiency, ${ }^{7}$ and so we apply it to our model. According to the method, the model to be estimated is

$$
\Delta Y_{i t}=\alpha \Delta Y_{i, t-1}+\beta \Delta X_{i t}+\Delta u_{i t}
$$

where the $\Delta s$ are the first-differenced terms of the corresponding variables in equation (1), e.g. $\Delta Y_{i t}=Y_{i t}-Y_{i, t-1}$ is the first difference of the dependent variable, FDI flows into country $i$ in year $t . \Delta Y_{i, t-1}$ is the one-year lagged value of the new dependent variable, $\Delta Y_{i t} . \Delta X_{i t}$ is a vector which includes all the explanatory variables from equation (1).

The model can be estimated in one or two-stage GMM. The two-stage method involves using the residuals from first stage to compute an optimal weighting matrix, which is subsequently applied to the second stage. In the following, we present only the one-stage estimates, from which robust standard errors can be constructed. In addition, Arellano and Bond (1991) warn against interpretation of coefficients within the two-stage framework, due to a likely underestimation of standard errors of the coefficients. In fact, we estimated with both methods and the

${ }^{7}$ The efficiency can be improved by using lagged values of both the instrumented variables and the instruments as additional instruments. For details on GMM estimation, see Arellano and Bond (1991), Arellano and Bover (1995), and Blundell and Bond (1998). 
Table 2. Dependent Variable: Inward FDI (Fixed-effect)

\begin{tabular}{|c|c|c|c|c|c|c|}
\hline & 1 & II & III & IV & $\mathrm{V}$ & VI \\
\hline CFDI & $\begin{array}{l}-0.090 \\
(0.363)\end{array}$ & $\begin{array}{c}0.308^{* *} \\
(0.157)\end{array}$ & $\begin{array}{l}1.081^{\text {**** }} \\
(0.312)\end{array}$ & $\begin{array}{c}0.607 \\
(0.726)\end{array}$ & $\begin{array}{l}1.190^{* * * *} \\
(0.306)\end{array}$ & $\begin{array}{c}0.672 \\
(0.773)\end{array}$ \\
\hline $\mathrm{FDI}_{t-1}$ & $\begin{array}{l}0.528^{* * *} \\
(0.049)\end{array}$ & $\begin{array}{l}0.153^{* * *} \\
(0.039)\end{array}$ & $\begin{array}{c}0.158^{* *} \\
(0.064)\end{array}$ & $\begin{array}{l}-0.028 \\
(0.165)\end{array}$ & $\begin{array}{c}0.150^{* *} \\
(0.062)\end{array}$ & $\begin{array}{l}-0.003 \\
(0.170)\end{array}$ \\
\hline GPCGR & $\begin{array}{l}-0.036 \\
(0.033)\end{array}$ & $\begin{array}{l}-0.017 \\
(0.013)\end{array}$ & $\begin{array}{c}-0.041^{* *} \\
(0.019)\end{array}$ & $\begin{array}{l}-0.031 \\
(0.032)\end{array}$ & $\begin{array}{l}-0.045^{* *} \\
(0.018)\end{array}$ & $\begin{array}{c}-0.034 \\
(0.034)\end{array}$ \\
\hline GDP & & $\begin{array}{c}2.017^{* *} \\
(0.927)\end{array}$ & $\begin{array}{l}5.786^{* * *} \\
(1.557)\end{array}$ & $\begin{array}{c}4.608^{*} \\
(2.602)\end{array}$ & $\begin{array}{l}6.176^{* * *} \\
(1.518)\end{array}$ & $\begin{array}{c}4.931^{*} \\
(2.649)\end{array}$ \\
\hline WFDI & $\begin{array}{l}0.797^{* * * *} \\
(0.299)\end{array}$ & $\begin{array}{l}0.588^{* * *} \\
(0.129)\end{array}$ & $\begin{array}{c}0.533^{* * *} \\
(0.158)\end{array}$ & $\begin{array}{c}0.326 \\
(0.262)\end{array}$ & $\begin{array}{l}0.701^{* * *} \\
(0.173)\end{array}$ & $\begin{array}{c}0.354 \\
(0.314)\end{array}$ \\
\hline WAGE & $\begin{array}{l}-0.275 \\
(0.458)\end{array}$ & $\begin{array}{c}0.355 \\
(0.274)\end{array}$ & $\begin{array}{c}-0.971^{*} \\
(0.560)\end{array}$ & $\begin{array}{l}-2.612^{* * *} \\
(0.963)\end{array}$ & $\begin{array}{l}-1.277^{* *} \\
(0.553)\end{array}$ & $\begin{array}{l}-2.600^{* * *} \\
(0.978)\end{array}$ \\
\hline ILLIT & & $\begin{array}{l}-0.465^{* *} \\
(0.198)\end{array}$ & $\begin{array}{c}-0.378^{*} \\
(0.228)\end{array}$ & $\begin{array}{l}-3.483^{* * *} \\
(1.125)\end{array}$ & $\begin{array}{l}-0.577^{* *} \\
(0.256)\end{array}$ & $\begin{array}{l}-3.271^{* * *} \\
(1.180)\end{array}$ \\
\hline OPEN & $\begin{array}{l}-0.009 \\
(0.008)\end{array}$ & $\begin{array}{l}-0.003 \\
(0.003)\end{array}$ & $\begin{array}{l}-0.005 \\
(0.006)\end{array}$ & $\begin{array}{l}-0.020^{*} \\
(0.012)\end{array}$ & $\begin{array}{l}-0.004 \\
(0.006)\end{array}$ & $\begin{array}{l}-0.019 \\
(0.013)\end{array}$ \\
\hline TARIFF & & & & $\begin{array}{c}0.050 \\
(0.072)\end{array}$ & & $\begin{array}{c}0.039 \\
(0.078)\end{array}$ \\
\hline INCTAX & & & & $\begin{array}{l}-0.017 \\
(0.020)\end{array}$ & & $\begin{array}{l}-0.015 \\
(0.021)\end{array}$ \\
\hline PSR & & & $\begin{array}{c}0.040^{* *} \\
(0.018)\end{array}$ & $\begin{array}{l}0.070^{* * *} \\
(0.027)\end{array}$ & $\begin{array}{c}0.036^{* *} \\
(0.018)\end{array}$ & $\begin{array}{c}0.062^{* *} \\
(0.029)\end{array}$ \\
\hline TELE & & & & & $\begin{array}{l}-0.808^{*} \\
(0.459)\end{array}$ & $\begin{array}{l}-0.107 \\
(0.834)\end{array}$ \\
\hline CRISIS & & $\begin{array}{l}-0.082^{*} \\
(0.048)\end{array}$ & $\begin{array}{l}-0.156^{* *} \\
(0.076)\end{array}$ & $\begin{array}{c}0.087 \\
(0.142)\end{array}$ & $\begin{array}{l}-0.131^{*} \\
(0.080)\end{array}$ & $\begin{array}{c}0.063 \\
(0.147)\end{array}$ \\
\hline ACCESS & & $\begin{array}{c}0.418^{* * *} \\
(0.147)\end{array}$ & $\begin{array}{c}0.560^{* * * *} \\
(0.189)\end{array}$ & $\begin{array}{l}0.823^{* * *} \\
(0.299)\end{array}$ & $\begin{array}{l}0.611^{\text {*** }} \\
(0.187)\end{array}$ & $\begin{array}{c}0.771^{* *} \\
(0.309)\end{array}$ \\
\hline Obs. & 157 & 132 & 101 & 62 & 99 & 61 \\
\hline R-squared & 0.707 & 0.792 & 0.807 & 0.802 & 0.803 & 0.794 \\
\hline
\end{tabular}

two-stage results were not qualitatively different. To check for robustness of the model, we also conducted two specification tests. The first is the Arellano and Bond test of second-order correlation in the first-differenced error terms, the SOC test. The second is the Sargan test of over-identification, which tests for correlation between the instruments that are excluded from the second-stage model and the residuals. Both tests are used to check the validity of the lagged instruments as well as the appropriateness of the model. 
Table 3. Dependent Variable: Inward FDI (Random-effect)

\begin{tabular}{|c|c|c|c|c|c|c|}
\hline & 1 & II & III & IV & $\mathrm{V}$ & VI \\
\hline \multirow{2}{*}{ CFDI } & -0.420 & 0.200 & 0.095 & 0.387 & 0.114 & 0.395 \\
\hline & $(0.347)$ & $(0.174)$ & $(0.221)$ & $(0.499)$ & $(0.230)$ & $(0.523)$ \\
\hline \multirow{2}{*}{$\mathrm{FDI}_{t-1}$} & $0.649^{* * *}$ & $0.235^{* * *}$ & $0.378^{* * *}$ & $0.373^{* * *}$ & $0.370^{* * *}$ & $0.391^{* * *}$ \\
\hline & $(0.038)$ & $(0.037)$ & $(0.059)$ & $(0.129)$ & $(0.061)$ & $(0.133)$ \\
\hline \multirow{2}{*}{ GPCGR } & $-0.053^{*}$ & -0.006 & -0.005 & -0.031 & -0.006 & -0.034 \\
\hline & $(0.031)$ & $(0.016)$ & $(0.019)$ & $(0.032)$ & $(0.019)$ & $(0.034)$ \\
\hline \multirow{2}{*}{ GDP } & & $0.792^{* * *}$ & $0.775^{* * *}$ & $0.936^{* * *}$ & $0.718^{* * *}$ & $0.849^{* * *}$ \\
\hline & & $(0.102)$ & $(0.124)$ & $(0.217)$ & $(0.132)$ & $(0.232)$ \\
\hline \multirow{2}{*}{ WFDI } & 0.404 & $0.571^{\text {*** }}$ & 0.259 & 0.073 & $0.342^{*}$ & 0.121 \\
\hline & $(0.281)$ & $(0.147)$ & $(0.173)$ & $(0.244)$ & $(0.191)$ & $(0.276)$ \\
\hline \multirow{2}{*}{ WAGE } & 0.195 & -0.041 & 0.092 & -0.130 & 0.141 & -0.095 \\
\hline & $(0.202)$ & $(0.116)$ & $(0.148)$ & $(0.172)$ & $(0.162)$ & $(0.195)$ \\
\hline \multirow{2}{*}{ ILLIT } & & -0.022 & 0.009 & $-0.886^{* *}$ & -0.029 & $-0.891^{* *}$ \\
\hline & & $(0.027)$ & $(0.028)$ & $(0.345)$ & $(0.044)$ & $(0.359)$ \\
\hline \multirow{2}{*}{ OPEN } & -0.005 & 0.004 & $0.009^{* * *}$ & $0.013^{* * *}$ & $0.010^{* * *}$ & $0.013^{* *}$ \\
\hline & $(0.004)$ & $(0.003)$ & $(0.003)$ & $(0.005)$ & $(0.004)$ & $(0.005)$ \\
\hline \multirow{2}{*}{ TARIFF } & & & & 0.027 & & 0.024 \\
\hline & & & & $(0.048)$ & & $(0.049)$ \\
\hline \multirow{2}{*}{ INCTAX } & & & & -0.021 & & -0.020 \\
\hline & & & & $(0.017)$ & & $(0.018)$ \\
\hline \multirow{2}{*}{ PSR } & & & 0.014 & 0.034 & 0.006 & 0.025 \\
\hline & & & $(0.017)$ & $(0.021)$ & $(0.018)$ & $(0.023)$ \\
\hline \multirow{2}{*}{ TELE } & & & & & -0.321 & -0.182 \\
\hline & & & & & $(0.308)$ & $(0.457)$ \\
\hline \multirow{2}{*}{ CRISIS } & & 0.001 & -0.010 & $-0.110^{* *}$ & -0.023 & $-0.117^{* *}$ \\
\hline & & $(0.016)$ & $(0.018)$ & $(0.044)$ & $(0.021)$ & $(0.047)$ \\
\hline \multirow{2}{*}{ ACCESS } & & 0.263 & 0.285 & 0.276 & 0.260 & 0.260 \\
\hline & & $(0.172)$ & $(0.197)$ & $(0.224)$ & $(0.200)$ & $(0.226)$ \\
\hline Obs. & 157 & 132 & 101 & 62 & 99 & 61 \\
\hline R-squared & 0.672 & 0.669 & 0.625 & 0.587 & 0.619 & 0.583 \\
\hline
\end{tabular}

\section{Empirical Results}

Tables 2 to 5 present the parameter estimates for determinants of CEECs' FDI inflows using different models: Feasible Generalized Least Squares with fixed effects (FGLS-FE) in Table 2, Feasible Generalized Least Squares with random effects (FGLS-RE) in Table $3,{ }^{8}$ Error Correction Two Stage Least Squares (EC2SLS) and Generalized Method of Moments (GMM) in Tables 4 and 5. Columns I through VI in each table compare results for the various specifications. 
Table 4. Dependent Variable: Inward FDI (EC2SLS)

\begin{tabular}{|c|c|c|c|c|c|c|}
\hline & 1 & II & III & IV & V & VI \\
\hline CFDI & $\begin{array}{c}-0.457 \\
(0.357)\end{array}$ & $\begin{array}{c}0.174 \\
(0.179)\end{array}$ & $\begin{array}{c}0.023 \\
(0.231)\end{array}$ & $\begin{array}{c}0.280 \\
(0.496)\end{array}$ & $\begin{array}{c}0.070 \\
(0.239)\end{array}$ & $\begin{array}{c}0.301 \\
(0.527)\end{array}$ \\
\hline $\mathrm{FDI}_{t-1}$ & $\begin{array}{c}0.651^{* * *} \\
(0.039)\end{array}$ & $\begin{array}{l}0.241^{\text {*** }} \\
(0.039)\end{array}$ & $\begin{array}{c}0.392^{* * *} \\
(0.062)\end{array}$ & $\begin{array}{l}0.408^{* * *} \\
(0.132)\end{array}$ & $\begin{array}{l}0.380^{* * *} \\
(0.064)\end{array}$ & $\begin{array}{l}0.404^{* * *} \\
(0.136)\end{array}$ \\
\hline GPCGR & $\begin{array}{l}-0.052 \\
(0.032)\end{array}$ & $\begin{array}{c}-0.007 \\
(0.016)\end{array}$ & $\begin{array}{l}-0.006 \\
(0.020)\end{array}$ & $\begin{array}{l}-0.034 \\
(0.032)\end{array}$ & $\begin{array}{l}-0.008 \\
(0.020)\end{array}$ & $\begin{array}{l}-0.035 \\
(0.034)\end{array}$ \\
\hline GDP & & $\begin{array}{l}0.770^{* * *} \\
(0.110)\end{array}$ & $\begin{array}{c}0.749^{* * *} \\
(0.136)\end{array}$ & $\begin{array}{c}0.881^{* * *} \\
(0.234)\end{array}$ & $\begin{array}{l}0.727^{* * *} \\
(0.139)\end{array}$ & $\begin{array}{l}0.880^{* * *} \\
(0.237)\end{array}$ \\
\hline WFDI & $\begin{array}{c}0.363 \\
(0.288)\end{array}$ & $\begin{array}{l}0.556^{* * *} \\
(0.151)\end{array}$ & $\begin{array}{c}0.269 \\
(0.177)\end{array}$ & $\begin{array}{c}0.038 \\
(0.242)\end{array}$ & $\begin{array}{c}0.335^{*} \\
(0.194)\end{array}$ & $\begin{array}{c}0.057 \\
(0.283)\end{array}$ \\
\hline WAGE & $\begin{array}{c}0.125 \\
(0.215)\end{array}$ & $\begin{array}{l}-0.041 \\
(0.121)\end{array}$ & $\begin{array}{c}0.085 \\
(0.156)\end{array}$ & $\begin{array}{c}-0.114 \\
(0.170)\end{array}$ & $\begin{array}{c}0.133 \\
(0.166)\end{array}$ & $\begin{array}{l}-0.101 \\
(0.197)\end{array}$ \\
\hline ILLIT & & $\begin{array}{l}-0.026 \\
(0.028)\end{array}$ & $\begin{array}{c}0.009 \\
(0.029)\end{array}$ & $\begin{array}{l}-0.891^{\text {*** }} \\
(0.343)\end{array}$ & $\begin{array}{l}-0.021 \\
(0.046)\end{array}$ & $\begin{array}{l}-0.903^{* *} \\
(0.357)\end{array}$ \\
\hline OPEN & $\begin{array}{r}-0.005 \\
(0.04)\end{array}$ & $\begin{array}{c}0.004 \\
(0.003)\end{array}$ & $\begin{array}{l}0.009^{* *} \\
(0.004)\end{array}$ & $\begin{array}{l}0.014^{* * *} \\
(0.005)\end{array}$ & $\begin{array}{l}-0.010^{* *} \\
(0.004)\end{array}$ & $\begin{array}{l}0.014^{* * *} \\
(0.005)\end{array}$ \\
\hline TARIFF & & & & $\begin{array}{c}0.015 \\
(0.048)\end{array}$ & & $\begin{array}{c}0.015 \\
(0.049)\end{array}$ \\
\hline INCTAX & & & & $\begin{array}{l}-0.015 \\
(0.017)\end{array}$ & & $\begin{array}{c}-0.016 \\
(0.018)\end{array}$ \\
\hline PSR & & & $\begin{array}{c}0.008 \\
(0.018)\end{array}$ & $\begin{array}{c}0.025 \\
(0.022)\end{array}$ & $\begin{array}{c}0.005 \\
(0.019)\end{array}$ & $\begin{array}{c}0.025 \\
(0.023)\end{array}$ \\
\hline TELE & & & & & $\begin{array}{c}-0.272 \\
(0.329)\end{array}$ & $\begin{array}{l}-0.065 \\
(0.097)\end{array}$ \\
\hline CRISIS & & $\begin{array}{l}-0.003 \\
(0.017)\end{array}$ & $\begin{array}{l}-0.019 \\
(0.019)\end{array}$ & $\begin{array}{l}-0.122^{* * *} \\
(0.044)\end{array}$ & $\begin{array}{l}-0.026 \\
(0.021)\end{array}$ & $\begin{array}{l}-0.124^{* * *} \\
(0.047)\end{array}$ \\
\hline ACCESS & & $\begin{array}{c}0.299^{*} \\
(0.177)\end{array}$ & $\begin{array}{c}0.301 \\
(0.202)\end{array}$ & $\begin{array}{c}0.276 \\
(0.222)\end{array}$ & $\begin{array}{c}0.283 \\
(0.204)\end{array}$ & $\begin{array}{c}0.274 \\
(0.224)\end{array}$ \\
\hline Obs. & 147 & 123 & 93 & 59 & 93 & 59 \\
\hline R-squared & 0.706 & 0.782 & 0.804 & 0.806 & 0.806 & 0.806 \\
\hline
\end{tabular}

Note: standard errors in parentheses. ${ }^{* * * *},{ }^{* * *}$ and ${ }^{*}$ indicate coefficient significant at 1,5 and $10 \%$, respectively.

Our results produce a positive coefficient of China FDI inflows for all models except those for GMM, which are negative but insignificant. The coefficient is strongly significant and positive within the fixed-effect framework. This implies that FDI inflows to China and the Central and Eastern European countries are not, as certain scholars and politicians may have worried, strongly competing against each other. Rather, as indicated by the mostly positive estimates, they may even at

${ }^{8}$ The Hausman test indicates the superiority of the Fixed-effect over Random-effect model, though both results are presented. 
Table 5. Dependent Variable: Inward FDI (GMM)

\begin{tabular}{|c|c|c|c|c|c|c|}
\hline & 1 & II & III & IV & $\mathrm{V}$ & VI \\
\hline CFDI & $\begin{array}{l}-0.268 \\
(0.274)\end{array}$ & $\begin{array}{l}-0.245 \\
(0.153)\end{array}$ & $\begin{array}{l}-0.213 \\
(0.186)\end{array}$ & $\begin{array}{l}-0.159 \\
(0.294)\end{array}$ & $\begin{array}{l}-0.211 \\
(0.188)\end{array}$ & $\begin{array}{c}-0.138 \\
(0.297)\end{array}$ \\
\hline $\mathrm{FDI}_{t-1}$ & $\begin{array}{l}0.647^{* * *} \\
(0.038)\end{array}$ & $\begin{array}{l}0.306^{* * *} \\
(0.036)\end{array}$ & $\begin{array}{l}0.446^{* * *} \\
(0.153)\end{array}$ & $\begin{array}{c}0.403^{* * *} \\
(0.128)\end{array}$ & $\begin{array}{l}0.441^{\text {*** }} \\
(0.054)\end{array}$ & $\begin{array}{c}0.426^{* * *} \\
(0.130)\end{array}$ \\
\hline GPCGR & $\begin{array}{l}-0.066^{* * *} \\
(0.025)\end{array}$ & $\begin{array}{c}0.012 \\
(0.016)\end{array}$ & $\begin{array}{c}0.012 \\
(0.018)\end{array}$ & $\begin{array}{l}-0.026 \\
(0.032)\end{array}$ & $\begin{array}{c}0.011 \\
(0.018)\end{array}$ & $\begin{array}{l}-0.025 \\
(0.034)\end{array}$ \\
\hline GDP & & $\begin{array}{c}0.541^{* * *} \\
(0.092)\end{array}$ & $\begin{array}{l}0.623^{\text {*** }} \\
(0.104)\end{array}$ & $\begin{array}{l}0.883^{* * *} \\
(0.215)\end{array}$ & $\begin{array}{l}0.555^{* * *} \\
(0.115)\end{array}$ & $\begin{array}{c}0.799^{* * *} \\
(0.230)\end{array}$ \\
\hline WFDI & $\begin{array}{c}0.497^{* *} \\
(0.248)\end{array}$ & $\begin{array}{c}0.270^{*} \\
(0.140)\end{array}$ & $\begin{array}{c}0.060 \\
(0.156)\end{array}$ & $\begin{array}{l}-0.036 \\
(0.232)\end{array}$ & $\begin{array}{c}0.121 \\
(0.170)\end{array}$ & $\begin{array}{l}-0.018 \\
(0.253)\end{array}$ \\
\hline WAGE & $\begin{array}{c}0.206 \\
(0.201)\end{array}$ & $\begin{array}{l}-0.050 \\
(0.124)\end{array}$ & $\begin{array}{c}0.137 \\
(0.151)\end{array}$ & $\begin{array}{l}-0.101 \\
(0.172)\end{array}$ & $\begin{array}{c}0.154 \\
(0.166)\end{array}$ & $\begin{array}{l}-0.100 \\
(0.196)\end{array}$ \\
\hline ILLIT & & $\begin{array}{c}-0.034 \\
(0.028)\end{array}$ & $\begin{array}{c}0.003 \\
(0.028)\end{array}$ & $\begin{array}{l}-0.781^{* *} \\
(0.339)\end{array}$ & $\begin{array}{l}-0.021 \\
(0.145)\end{array}$ & $\begin{array}{l}-0.767^{* *} \\
(0.346)\end{array}$ \\
\hline OPEN & $\begin{array}{l}-0.005 \\
(0.004)\end{array}$ & $\begin{array}{c}0.001 \\
(0.003)\end{array}$ & $\begin{array}{c}0.008^{* *} \\
(0.003)\end{array}$ & $\begin{array}{l}0.012^{* * *} \\
(0.005)\end{array}$ & $\begin{array}{c}0.008^{* *} \\
(0.004)\end{array}$ & $\begin{array}{c}0.012^{* *} \\
(0.005)\end{array}$ \\
\hline TARIFF & & & & $\begin{array}{l}-0.003 \\
(0.043)\end{array}$ & & $\begin{array}{c}0.001 \\
(0.045)\end{array}$ \\
\hline INCTAX & & & & $\begin{array}{l}-0.023 \\
(0.017)\end{array}$ & & $\begin{array}{l}-0.020 \\
(0.018)\end{array}$ \\
\hline PSR & & & $\begin{array}{c}0.012 \\
(0.018)\end{array}$ & $\begin{array}{c}0.032 \\
(0.021)\end{array}$ & $\begin{array}{c}0.005 \\
(0.019)\end{array}$ & $\begin{array}{c}0.024 \\
(0.023)\end{array}$ \\
\hline TELE & & & & & $\begin{array}{l}-0.189 \\
(0.310)\end{array}$ & $\begin{array}{l}-0.025 \\
(0.442)\end{array}$ \\
\hline CRISIS & & $\begin{array}{c}0.024 \\
(0.016)\end{array}$ & $\begin{array}{c}-0.005 \\
(0.018)\end{array}$ & $\begin{array}{l}-0.101^{* *} \\
(0.044)\end{array}$ & $\begin{array}{l}-0.015 \\
(0.021)\end{array}$ & $\begin{array}{l}-0.104^{* *} \\
(0.046)\end{array}$ \\
\hline ACCESS & & $\begin{array}{c}0.310^{*} \\
(0.184)\end{array}$ & $\begin{array}{c}0.330^{*} \\
(0.202)\end{array}$ & $\begin{array}{c}0.329 \\
(0.222)\end{array}$ & $\begin{array}{c}0.311 \\
(0.204)\end{array}$ & $\begin{array}{c}0.307 \\
(0.224)\end{array}$ \\
\hline Obs. & 157 & 132 & 101 & 62 & 99 & 61 \\
\hline Sargan test & 0.040 & 0.483 & 0.480 & 0.473 & 0.480 & 0.473 \\
\hline SOC test & 0.472 & 0.387 & 0.660 & 0.097 & 0.541 & 0.095 \\
\hline
\end{tabular}

Notes: standard errors in parentheses. ${ }^{* * * *},{ }^{* *}$ and ${ }^{*}$ indicate coefficient significant at 1,5 and $10 \%$, respectively. Sargan test ( $p$-value): null hypothesis is no misspecification with instrument sets. SOC test ( $p$-value): null hypothesis of no second-order correlation in differenced errors.

some point work as complements. ${ }^{9}$ Consequently, strong growth of China's inward FDI should not be taken as a menace to CEECs in crowding out the FDI flows into

\footnotetext{
${ }^{9}$ As we mentioned earlier, our interpretation of this result is that China and CEECs are at least loosely in the same global supply chain. However, another interpretation is that multinationals are hedging their investment in different locations to reduce risks. We are indebted to a referee for suggesting this interesting interpretation.
} 
the region. However, the loose relationship between the two streams of FDI may result from the relatively long distance between the two regions. As indicated in trade theory, geographic distance between two parties weakens bilateral trade, as trade costs and other barriers tend to rise. It may be true that both geographic distance and cultural difference between China and CEECs contribute to their unique attributes as hosts for FDI, and therefore foreign investors in general do not necessarily consider the two markets as competitors.

Another possible explanation for the loose connection lies in the different types of FDI that dominate in the two markets. On one hand, as documented in various studies (Navaretti and Venables, 2004), horizontal-type FDI, which is mainly for market-seeking, is believed to be prevalent among the transition economies. On the other hand, due to its relative low cost of labor, China is believed to have an ever growing presence of vertical FDI, whose main purpose is to minimize global production costs across all stages. Their focus on different goals led foreign investors to choose each market accordingly without necessarily placing one as a substitute for the other.

Across all specifications, lagged FDI is strongly significant and positive, indicating a well-founded self-reinforcing effect of the dependent variable's past value on its current value. Since FDI is considered to be long-term capital investment and irreversible in the short run, foreign investors are more cautious about the destination. When the host market has successfully obtained numbers of large establishments via foreign investors, potential investors generally consider this a sign of a sound investment environment. To them, such establishments could also be associated with positive externalities in the host country such as technology spillovers, advanced labor skills and efficient production and supplier network, which can lead to further FDI inflows through a positive feedback channel. In line with recent empirical findings in support of the agglomeration effect in the U.S. (Wheeler and Mody, 1992) and Japanese FDI (Head, Ries, and Swenson 1995), this study suggests that the same effect also exists in transition economies. This partly explains why the relatively advanced economies in the region, which began FDI absorption much earlier than the others, continue to attract much larger shares of FDI flows into the region.

The other variables generally get the expected signs. With country size proxied by GDP level, its coefficient is consistently positive and strongly significant at the $1 \%$ level across all models. As the literature suggests that horizontal FDI is more attracted to host countries with large markets, our result seems to be consistent with 
the early finding of dominant horizontal FDI among CEECs. The variable WFDI, which uses world FDI outflows to capture the supply-side effect on CEECs' FDI inflows, carries a positive sign and is significant for the various specifications. It is in our belief that the inclusion of this global supply control factor avoids a possible upward bias in the estimation of the China effect.

Our results show that openness to trade is mainly positive and strongly correlated with FDI inflows. Since the variable is known as an indicator of a liberal trade environment in the host country, its positive estimate implies that fewer regulatory restrictions and trade barriers tend to facilitate international trade and promote FDI flows. One thing to note is that, although our results support a significantly positive correlation, the coefficient is small in magnitude, some estimates even being negative. In fact, in the empirical literature on FDI, a negative impact of openness to trade on FDI has been found in a number of studies. One possible explanation, as pointed in Hausmann and Fernandez (2000), is that openness to trade correlates with the degree of sophistication of the host financial system, which in turn might be negatively correlated with FDI. The small magnitude of the coefficient may be a result of this.

Manufacturing wage rate, a proxy for labor costs, carries a negative but usually insignificant sign. A strong negative coefficient on wage rates would imply dominance of vertical FDI in host market. However, as suggested by the previous analysis, FDI into CEECs is predominantly horizontal, with a focus on market penetration. As a result, labor costs are more likely to be downplayed by foreign investors who are mainly interested in accessing larger markets and seeking efficiency. To them, labor quality in the host market, a critical factor for operational productivity and efficiency, is of much greater relevance. In line with this reasoning, our labor quality variable, proxied by illiteracy rate, is found to be negative and significant. Thus a low level of skilled labor, indicated by a high illiteracy rate, tends to deter FDI inflows, reflecting the importance of labor quality in determining CEECs' FDI inflows.

In the literature, a tariff is often considered an integral part of trade costs, which are found to have a significant impact on FDI flows. However, on the aggregate level, their sign becomes ambiguous due to the opposite effects on horizontal and vertical FDI. Specifically, they tend to attract horizontal FDI for domestic market penetrating purposes, but to repel vertical FDI due to cost concerns. Thus the sign will depend on which kind of FDI is dominant in the particular host country. Our results show a consistently positive though insignificant estimate, once again 
suggesting the dominance of horizontal FDI for transition economies. The tax burden, proxied by the corporate income tax rate, while obtaining the right sign, seems to have only a marginal effect on FDI. One possible explanation, according to an OECD study (2003), is that tax incentives may in certain cases be inefficient in promoting FDI. As they found in their report, large MNCs are becoming more adept at alleviating their own tax burdens through sophisticated tax planning well before the operation. As a result, those tax incentives offered by a host country often lose their importance over time, and so are ignored. In the extreme, they may even be counterproductive, since these tax policies are considered to be nontransparent, insecure or bureaucratically infeasible.

There is evidence that the political and institutional stability of a host country can boost foreign investors' confidence. Our proxy, the ICRG political stability risk index, carries a positive sign across all models and is strongly significant for the fixed-effect model. This finding is consistent with the literature, as the index assigns a higher score to those countries with political and financial stability, efficient institutional structure and strong law enforcement, all of which enhance FDI attraction.

Main telephone lines per thousand people as a proxy for host-country infrastructure quality, is statistically insignificant and seems to carry the wrong sign. A possible reason lies in the fading importance of traditional communication technique in the face of current innovations. Our positive coefficient on the accession dummy indicates that the fifth EU enlargement does help new members in the region to attract more FDI. Admission of a CEEC to the EU can be considered a worldwide recognition of the country's success in its political and economic reforms. As a result, foreign investors feel more comfortable about investing in those markets, due to favorable investment environments.

In general, we do not find any crowding out effect of China FDI on the Central and Eastern European countries. In some cases, China's FDI inflows may even to induce more FDI into the region. Our results also show that, of the determinants, the host country's market size, trade environment, as well as its labor quality, all have a strong influence on FDI flows into CEECs.

\section{Robustness Checks ${ }^{10}$}

The GMM estimation procedure aims to correct for the potential endogeneity problem. To ensure the appropriateness of our model under GMM, we need to 
verify that there is no second-order serial correlation of first-differenced error terms and the instrument sets used in the estimation are properly specified. For this purpose, two tests are performed: the Allerano \& Bond second-order correlation (SOC) test and the Sargan test. The p-value from Table 5 for both the SOC test (null of no correlation) and Sargan test (null of no instrument misspecification) indicate that neither of the null hypotheses can be rejected. Thus the results confirm the properness of our interpretation for the GMM framework.

To further test the robustness of our model, we try re-estimate by dropping individual countries from our sample, one at a time. It turns out that the major conclusion remains valid. China FDI inflows are not growing at the expense of FDI flows into Central and Eastern Europe. Market size, degree of trade liberalization, as well as labor quality remain significant in guiding FDI location choices among CEECs. In order to take a closer look at the impact of host-country political and institutional environment, we replace the ICRG index PSR with three separate indicators, namely, Corruption, Law and order, and Government stability. A higher score in each category corresponds to above-average quality of host market in that respect. Again, the results are similar to the previous estimates, with positive signs on each individual category. And our results for the China effect remain unchanged.

Additionally, in an attempt to control for a possible contagious effect of the financial crises in Asia in 1997 and later in Russia in 1998 on CEECs, we add a dummy variable, crisis, which takes the value 1 for year 1997 and year 1998 and 0 otherwise. The result looks compelling. The significant and negative coefficient suggests that the two consecutive financial crises, by severely hurting the global banking system and capital markets, lessened foreign investors' willingness and capability to invest in CEECs. However, inclusion of the dummy does not change our findings regarding the China effect.

\footnotetext{
${ }^{10}$ Other interesting and very useful extensions of our emprical research will be to look at the sources of the FDI going to China and going to CEECs. In addition, studying the FDI inflows by sectors will provide additional insights. We are indebted to a referee for these very insightful suggestions.
} 


\section{Conclusion}

China's emergence as a leading recipient of FDI in the world follows its implementation of an open door policy and market economy reform over the last three decades. The successful transition experience of many Central and Eastern European countries also enables them to attract an increasing share of foreign investment from the world, particularly from the European Union. At the same time, results from existing studies strongly suggest that FDI into emerging economies often serves to facilitate the operation of production networks. Given these different but related global trends, what is the relationship between FDI into China and FDI into the CEECs? We hypothesize three possible relationships: China and CEECs are in different distinct regional production networks, implying that the impact of China on FDI into CEECs is zero; or China and CEECs jointly participate in a global supply chain, so that FDI into China and into the CEECs are positively related; or MNCs may view China and CEECs as rival production sites, so that the China effect on FDI into CEECs is negative.

Despite its significant academic and policy implications, the question we pose here remains unresolved due to a lack of related empirical work. In this paper, we employ panel data to study this so-called China effect in detail. Specifically, we compare empirical estimates for 15 Central and Eastern European countries over a 15-year period from 1990-2004, using four different econometric approaches: FGLS with Random effects, FGLS with fixed effects, EC2SLS and GMM. Our key empirical result is that generally the China effect variable is insignificant. When the variable is significant, the sign of the coefficient is positive. This result supports the general conclusion that there is only a weak relationship between FDI into China and FDI into the CEECs. In some regressions, FDI into China and FDI into CEECs are positively and significantly related. In other words, there is some evidence that China and CEECs are a global supply chain.

It can be argued that with certain Central and Eastern European countries having relatively highly-skilled labor forces and China one of the world's largest markets with relatively low-cost labor, the large MNCs may choose to fragment their production processes into both locations in order to better accommodate the local demand and their increasingly sophisticated global supply chains. To this extent, our results might be considered as further support for the claim that China and the Central and Eastern European countries, by undergoing the market economy transition through different approaches, are becoming integral to the global 
production network. It can also be mentioned that FDI into the CEECs has been more dominated by service sector investments than has FDI into China, which is of course another indication of the different strategies chosen by the MNCs for these markets. Meanwhile, our analysis confirms the predominance of host-country characteristics such as market size, degree of trade liberalization and labor quality, as well as a global-wise healthy capital market, in promoting FDI flows. We think that these findings provide some helpful policy implications for the Central and Eastern European countries for becoming attractive FDI destinations.

\section{Acknowledgements}

We are indebted to very constructive and useful comments by an anonymous referee and the helpful suggestions of an editor. The findings, interpretations, and conclusions expressed herein are those of the authors and do not necessary reflect the views of their institutions or The World Bank Group, its Executive Directors, or its staff.

Received 28 May 2008, Revised 21 October 2008, Accepted 22 October 2008

\section{References}

Aminian, N., K.C. Fung, H. Iizaka and A. Siu(2008), "Trade in Components and Parts and Foreign Direct Investment in East Asia," in Emerging Trade Issues for Developing Countries in the Asia-Pacific Region, United Nations Economic and Social Commission, Studies in Trade and Investment, United Nations Publication, forthcoming.

Arellano and Bover (1995), "Another Look at Instrumental Variable Estimation of ErrorComponents Models", Journal of Econometrics, 68, pp. $29-51$.

Arellano, M. and S. Bond (1991), "Some Tests of Specification for Panel Data: Monte Carlo Evidence and an Application to Employment Equations," Review of Economic Studies, 58, pp. 277-97.

Baltagi, B. H. (1981), "Simultaneous Equations with Error Components," Journal of Econometrics, 17, pp. 189-200.

Baltagi, B. H. (2001), Econometric Analysis of Panel Data, Chichester, England: John Wiley \& Sons, LTD.

Barry, F. and A. Hannan (2001), "Will Enlargement Threaten Ireland's FDI Inflows?”, Quarterly Economic Commentary, Dublin: ESRI.

Barry, F. (2002), EU Accession and Prospective FDI Flows to CEE Countries: a View 
from Ireland. In: Lipsey, Robert E.(Ed.), Real and Monetary Aspects of FDI in Industrial Countries, Deutsche Bundesbank/Springer Verlag.

Bedi, A. S. and A. Cieslik(2002), "Wages and Wage Growth in Poland," Economics of Transition, 10(1), pp. 1-27.

Blundell, R., and S. Bond (1998), "Initial Conditions and Moment Restrictions in Dynamic Panel Data Models", Journal of Econometrics, 87, pp. 111-143.

Chantasasawat, B., Fung, KC, Iizaka, H, and Alan Siu (2004), "The Giant Sucking Sound: Is China Diverting FDI from Other Asian Economies?", Asian Economic Papers, v.3, issue 3, pp. 122-140.

Cravino, J., D. Lederman and M. Olarreaga (2007), "Substitution between Foreign Capital in China, India, the Rest of the World, and Latin America; Much Ado about Nothing?", Policy Research Working Paper, No. 4361, Washington DC: The World Bank.

EBRD (2007), Structural change indicators, file on http://www.ebrd.com/country/sector/ econo/stats/index.htm, accessed in April 2008.

Eichengreen, B. and H. Tong (2005), "Is China's FDI Coming at the Expense of Other Countries?", NBER Working Paper, No. 11335, Cambridge, MA.

Fung, K. C., Hitomi Iizaka and Alan Siu (2003), "Japanese Direct Investment in China", China Economic Review, 14, 304-15.

Fung, K. C., Hitomi Iizaka and Stephen Parker (2002), "Determinants of U.S. and Japanese Direct Investment in China", Journal of Comparative Economics, 30, 56778.

Hanson, G., R. Mataloni and M. Slaughter (2001), "Expansion Strategies of the US Multinational Firms", NBER Working Paper, No. 8433, Cambridge, MA.

Hausmann, Ricardo and Eduardo Fernandez-Arias (2000), "Foreign Direct Investment: Good Cholesterol?", Inter-American Development Bank Working Paper, No. 417, Washington D.C.

Head, K., Ries, J., and Swenson, D. (1995), "Agglomeration Benefits and Location Choice: Evidence from Japanese Manufacturing Investment in the United States", Journal of International Economics, 38, 223-247.

Henisz, Witold (2000), "The Institutional Environment for Multinational Investment", Journal of Law, Economics and Organization, 16, 334-64.

Hunya, G. (2004), Foreign Direct Investment in South-East Europe 2003-2004, Vienna Institute for International Economic Studies.

International Monetary Fund (1993), Balance of Payments Manual, $5^{\text {th }}$ Ed., Washington, D.C.: IMF.

Lall, S. and Y. Zhou (2005), "The Impact of China's FDI Surge on FDI in South-East Asian: Panel Data Analysis for 1986-2001”, Transnational Corporations, Vol. 14, No. 1.

Markusen, R. M. and K. E. Maskus (1999), Discriminating among Alternative Theories of the Multinational Enterprise, NBER Working Paper, No. 7164, Cambridge, MA.

Navaretti, B. G. and A. J. Venables (2004), Multinational Firms in the World Economy, 
Princeton, N.J.: Princeton University Press.

Norman G.(1995), "Japanese Foreign Direct Investment: The Impact on the European Union," in N. M. Healey (ed.), The Economics of the New Europe: From Community to Union, London: Routledge.

OECD (2003), Tax Policy Assessment and Design in Support of Direct Investment, Paris: OECD.

Price Waterhouse Coopers (1990-2004), Worldwide Tax Summaries, Various Issues, Price Waterhouse Coopers LLP.

Sachwald, F. (2004), "The Integration of China and East European Countries in Global Networks," Les Etudes de l'IFRI 2, Paris: IFRI.

Wei, Shanjin (2000), "How Taxing is Corruption on International Investors?" Review of Economics and Statistics, 82(1), pp. 1-11.

Wheeler D. and Mody A. (1992), "International Investment Location Decisions: the Case of US Firms," Journal of International Economics, 33(1-2), pp. 57-76.

World Investment Directory (2003), Central and Eastern Europe, 8, New York and Geneva: United Nations. 